\title{
STUDI FENOMENOLOGI PRAKTIK AKUNTANSI UNTUK PENGELUARAN EKSPLORASI PADA PERUSAHAAN PERTAMBANGAN DI PT VALE INDONESIA TBK.
}

\author{
Oktafiani Hasan \\ Jurusan Akuntansi, Universitas Muhammadiyah Palopo \\ oktafianihasan@gmail.com
}

\begin{abstract}
ABSTRAK
Penelitian ini bertujuan untuk mengetahui Praktik akuntansi untuk pengeluran eksplorasi pada perusahaan pertambangan di PT Vale Indonesia. Metode penelitian yang digunakan adalah kualitatif (anti mainstream) dengan paradigma interpretif pada studi fenomenologi. Teknik pengumpulan data menggunakan teknik wawancara secara mendalam dengan informan yang telah ditentukan. Informan dalam penelitian ini yaitu orang-orang yang berhubungan dengan pihak akunting untuk pengeluaran eksplorasi dan pihak-pihak yang berada di lapangan pada kegiatan eksplorasi. Adapun hasil dari penelitian ini yaitu pengeluaran sehubungan dengan kegiatan eksplorasi di suatu pertambangan yakni PTVI di akui sebagai cost yakni, cost eksplorasi dan bukan sebagai suatu aset seperti yang ada pada acuan standar PSAK No.64
\end{abstract}

Kata Kunci : Praktik Akuntansi, Cost eksplorasi, Aset Eksplorasi, Pertambangan.

\section{ABSTRACT}

This study aims to determine accounting practices for exploration exploration in mining companies at PT Vale Indonesia. The research method used is qualitative (anti mainstream) with an interpretive paradigm in phenomenology studies. Data collection techniques use in-depth interviewing techniques with pre-determined informants. The informants in this study were people who deal with accounting for exploration expenditures and parties in the field in exploration activities. The results of this study, namely expenditures related to exploration activities in a mine is PTVI, are recognized as costs, namely exploration costs and not as assets as in the standard reference PSAK No.64

Keywords: Accounting Practices, Cost of Exploration, Exploration Assets, Mining.

\section{PENDAHULUAN}

Industry pertambangan memiliki karakteristik yang unik di banding industry lainnya salah satunya adalah mengenai aktivitas pencarian cadangan sumber daya mineral (Eksplorasi) yang bersifat gambling/untung-untungan Adanya perusahaan pertambangan khususnya didaerah kabupaten Luwu Timur Provinsi Sulawesi Selatan yang memiliki perusahaan tambang nikel dan merupakan satu-satunya tambang nikel yang berada di kawasan timur Indonesia tepatnya di Kabupaten Luwu Timur yang dikenal dengan nama PT. Vale Indonesia banyaknya anggaran yang dikeluarkan PT. Vale Indonesia Tbk dalam membantu program-program pemerintah Sulawesi Selatan untuk mengembangkan masyarakat di sekitarnya (Fardani, 2012).

Salah satu kegiatan yang cukup unik menurut peneliti dalam industry pertambangan yakni adanya kegiatan eksplorasi dalam industry pertambangan merupakan kegiatan pencarian cadangan sumber daya alam dan kegiatan ini merupakan tahap awal dilakukan sebelum masuk ke tahap operasi. Eksplorasi sumber daya alam menurut (Pamungkas dan Rusherliyanti, 2015) adalah 
Vol. 05 No. 02 Juni

ISSN 2339-1502

mencari tahu keberadaan suatu objek geologi batu bara, mineral maupun akuntansi minyak dan gas bumi, juga geologi yang bermanfaat bagi kesejahteraan manusia maupun mempunyai dampak negative, seperti adanya sesar jenis batuan tertentu yang keberadaannya pun diketahui secara mendetil. (Salendrez and Tang, 2016) Karena biaya eksplorasi dan evaluasi yang tinggi yang dikeluarkan oleh perusahaan tambang, kebijakan akuntansi yang tepat harus digunakan untuk memperhitungkan biaya-biaya ini. kebijakan akuntansi yang diperlukan untuk memberikan informasi lebih handal dan relevan dalam laporan keuangan pada efek dari transaksi, peristiwa atau kondisi lain pada posisi keuangan entitas.

Penerapan SAK atau Standar akuntansi keuangan hasil adopsi dari IFRS bagi industri pertambangan di Indonesia sangatlah penting, mengingat sektor ini telah menjadi salah satu aktivitas perdagangan yang sedang menorehkan keberhasilannya di mata dunia internasional. (Danzigar, 2014) IFRS 6 mensyaratkan perusahaan untuk mengembangkan kebijakan akuntansi yang menentukan jenis pengeluaran yang diakui sebagai aset eksplorasi dan evaluasi (E\&E) dan menerapkan kebijakan secara konsisten. Dari fokus penelitian serta rumusan masalah yang telah dituliskan di atas maka tujuan dari penelitian ini adalah untuk mengetahui bagaimana praktik akuntansi untuk pengeluaran aktivitas eksplorasi di PT Vale Indonesia. Studi literatur dalam penelitian ini akan menjelaskan dan mendeskripsikan perkembangan mengenai konsep pengeluaran Eksplorasi jika ditinjau dari perspektif pengakuan, pengukuran, penilaian, dan penyajian.

\section{TINJAUAN PUSTAKA}

\section{Teori Stakeholder}

Teori Stakeholder merupakan teori yang menyatakan bahwa perusahaan bukanlah entitas yang hanya beroperasi untuk kepentingan sendiri, namun harus memberikan manfaat kepada seluruh stakeholder-nya (pemegang saham, kreditor, konsumen, supplier, pemerintah, masyarakat, analis, dan pihak lain). . Tujuan utama dari teori stakeholder adalah untuk membantu manajemen perusahaan dalam meningkatkan penciptaan nilai sebagai dampak dari aktivitas-aktivitas yang dilakukan dan meminimalkan kerugian yang mungkin muncul bagi stakeholder (Ghozali \& Chairil, 2007: 409).

\section{Standar Akuntansi Keuangan}

Standar akuntansi keuangan (SAK) yang dijelaskan dalam http://iaiglobal.or.id adalah 
Vol. 05 No. 02 Juni

ISSN 2339-1502

Pernyataan Standar Akuntansi Keuangan (PSAK) dan Interpretasi Standar Akuntansi Keuangan (ISAK) yang diterbitkan oleh Dewan Standar Akuntansi Keuangan Ikatan Akuntan Indonesia (DSAK IAI) dan Dewan Standar Syariah Ikatan Akuntan Indonesia (DSAS IAI) serta peraturan regulator pasar modal untuk entitas yang berada di bawah pengawasannya.

Laporan keuangan yang baik dihasilkan pula dari standar akuntansi dan auditor yang berkualitas serta praktik tata kelola yang baik. Dan standar akuntansi yang baik pula dapat dicapai jika memiliki kerangka konseptual yang berkualitas. Martani et al., (2014:15) menjelaskan bahwa standar akuntansi berisikan pedoman penyusunan laporan keuangan.

\section{Laporan Keuangan}

PSAK No. 1 paragraf 10 bahwa Laporan keuangan adalah suatu penyajian terstruktur dari posisi keuangan dan kinerja keuangan suatu entitas. Tujuan laporan keuangan adalah memberikan informasi mengenai posisi keuangan, kinerja keuangan, dan arus kas entitas yang bermanfaat bagi sebagian besar kalangan pengguna laporan keuangan dalam pembuatan keputusan ekonomi.

\section{Pernyataan Standar Akuntansi Keuangan No. 64}

Berdasarkan PSAK 64 mengatur hal atas kegiatan eksplorasi dan evaluasi sumber daya mineral. Secara khusus PSAK 64 mensyaratkan :

Pengembangan terbatas atas praktik akuntansi untuk pengeluaran eksplorasi dan evaluasi; Entitas menilai apakah aset tersebut mengalami penurunan nilai sesuai dengan pernyataan ini dan mengukur setiap penurunan nilai sesuai dengan PSAK 48 (revisi 2009) : Penurunan Nilai Aset; Pengungkapan atas jumlah yang timbul dari eksplorasi dan evaluasi sumber daya mineral dalam laporan keuangan dan membantu pengguna laporan keuangan untuk memahami jumlah, waktu, dan kepastian atas arus kas masa depan dari setiap aset eksplorasi dan evaluasi yang diakui.

Lebih lanjut (IAI, 2012) Paragraf 8 PSAK 64 Entitas menentukan suatu kebijakan akuntansi yang spesifik yang mana pengeluaran diakui sebagai aset eksplorasi dan menerapkannya secara konsisten. Dalam menentukan kebijakan akuntansi ini, entitas mempertimbangkan tingkat pengeluaran yang dapat dikaitkan dengan penemuan sumber daya mineral.

\section{Kegiatan Usaha Pertambangan}

Dalam Undang-Undang Republik Indonesia No. 4 Tahun 2009 tentang Pertambangan Mineral 
Dan Batubara Pasal 1 angka 1 dijelaskan bahwa Pertambangan adalah sebagian atau seluruh tahapan kegiatan dalam rangka penelitian, pengelolaan dan pengusahaan mineral atau batubara yang meliputi penyelidikan umum, eksplorasi, studi kelayakan, konstruksi, penambangan, pengolahan dan pemurnian, pengangkutan dan penjualan, serta kegiatan pasca tambang. Lebih jelas lagi, (Kurniawan, 2017) menjelakan tentang usaha pertambangan yakni, semua usaha yang dilakukan oleh seseorang atau badan hukum/badan usaha untuk mengambil bahan galian dengan tujuan untuk dimanfaatkan lebih lanjut bagi kepentingan manusia.

\section{Penelitian Terdahulu}

Penelitian yang berfokus pada praktik akuntansi untuk pengeluaran eksplorasi belum banyak dilakukan di Indonesia dikarenakan adanya keterbatasan sumberdaya informasi. Penelti sebelumnya lebih banyak melakukan penelitian di industry migas dengan melihat kesesuian praktik IFRS 6 yang diterapkan, pada penelitian ini peneliti mengungkapkan bagaimana praktik akuntansi untuk aktivitas eksplorasi dalam industry pertambangan di PT Vale dengan melihat kesesuaiannya dengan PSAK. (Dwipuspasari, 2011) juga dalam penelitiannya membandingkan kesesuaian antara kebijakan akuntansi pada PT. Bukit Asam (Persero) dengan PSAK Nomor 33 (Revisi 2011). Terlihat bahwa PT. Bukit Asam (Persero) Tbk telah sesuai dengan PSAK No. 33 (revisi 2011) tentang akuntansi pertambangan. Sedangkan (Pamungkas \& Rusherlistyani, 2015) mengatakan bahwa penerapan PSAK 64 yang diadopsi oleh IFRS (Internasional Financial Reporting Standar) kurang sesuai diterapkan di Indonesia, dikarenakan karakteristik eksplorasi berbeda pada masing-masing industri pertambangan dan migas di Indonesia. Lebih lanjut penelitian yang dilakukan oleh (Riveta, 2012) bahwa perlakuan akuntansi atas biaya ekspolarasi dan evaluasi PT. Medco Energi Internasional Tbk. Belum sepenuhnya sesuai dengan PSAK No. 64.

\section{Kerangka pikir}

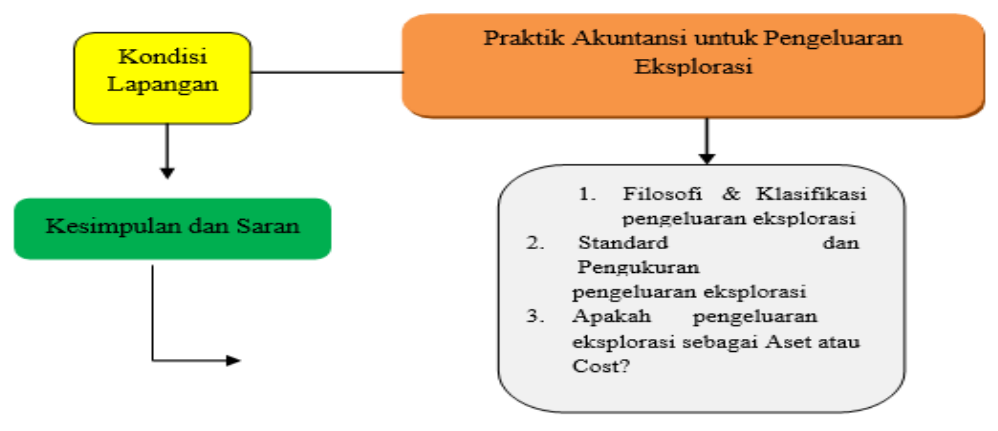

Oktafiana Hasan 4 | 14 


\section{METODE PENELITIAN}

Metode yang digunakan pada penelitian ini adalah penelitian kualitatif. Penelitian kualitatif dimaksudkan untuk mencari makna, pemahaman, pengertian, verstehen tentang suatu fenomena, kejadian, maupun kehidupan manusia dengan terlibat langsung dan tidak langsung dalam setting yang diteliti, konstektual dan menyeluruh. Peneliti bukan mengumpukan data sekali jadi atau langsung sekaligus melainkan melalui tahap-demi tahap makna disimpulkan selama proses berlangsung dari awal sampai akhir kegiatan, bersifat naratif dan holistic (Yusuf, 2017).

Fenomenologi memiliki niat untuk mendeskripsikan berbagai pengalaman, bukan sekumpulan penjelasan atau analisis sebuah deskripsi fenomenologi akan sangat dekat dengan kealamiahan dari sesuatu, melaui deskripsi fenomena ditampilkan dalam bentuk apa adanya, beserta tampilan kealamiahannya dan makna yang ada di baliknya deskripsi itu menjadi seolah dihidupkan dalam ketepatan dan kelengkapan perangkatnya dan hidupnya fenomenea tersebut punya kesamaan antara yang ada di dalam kesadaran dengan yang terlihat oleh indera kita.

\section{Lokasi/Tempat dan Waktu Penelitian.}

Lokasi penelitian peneliti adalah di PT. Vale Indonesia Tbk, Jl. Ternate No.44, Sorowako, Nuha, Kabupaten Luwu Timur, Sulawesi Selatan 92984. Seperti yang diketahui bahwa PT. Vale Indonesia adalah salah satu perusahaan pertambangan nikel yang terbesar didunia. sementara itu, untuk waktu penelitian yang digunakan April - Mei 2019 yakni, di departement accounting dan department mining.

\section{Populasi dan Sampel}

Dalam penelitian kualitatif tidak dikenal dengan istilah populasi, karena penelitian kualitatif berangkat dari kasus tertentu yang ada pada situasi sosial tertentu dan hasil kajiannya tidak akan diberlakukan ke populasi, tetapi ditransferkan ke tempat lain pada situasi sosial yang memiliki kesamaan dengan situasi sosial pada kasus yang dipelajari. Sampel di dalam penelitian kualitatif tidak dinamakan responden tetapi sebagai narasumber, atau partisipan, informan, teman dan guru dalam penelitian. Adapun teknik pengambilan sampel dalam penelitian ini dengan menggunakan Snow ball Sampling makin lama semakin terarah ke dalam focus penelitian.

Jadi, untuk penentuan sampel dalam penelitian kualitatif dilakukan saat peneliti memasuki lapangan dan selama penelitian berlangsung (emergent sampling design). Caranya yaitu, peneliti memilih orang tertentu yang dipertimbangkan akan memberikan data yang diperlukan; 
Vol. 05 No. 02 Juni

ISSN 2339-1502

selanjutnya berdasarkan data atau informasi yang diperoleh dari sampel sebelumnya itu, peneliti dapat menetapkan sampel lainnya yang dipertimbangkan akan memberikan data lebih lengkap (Futri, 2018).

\section{Instrumen dan Informan Penelitian.}

(Sugiyono, 2009) Informan merupakan orang yang menguasai dan memahami data, informasi, ataupun fakta dari suatu objek penelitian. Instrumen dalam penelitian ini adalah observasi, wawancara, dan dokumentasi. dalam penelitian ini dibutuhkan manusia sebagai peneliti karena manusia dapat menyesuaikan sesuai dengan keadaan lingkungan. Oleh karena itu, peneliti sebagai instrumen juga harus "divalidasi” seberapa jauh peneliti siap melakukan penelitian yang selanjutnya terjun ke lapangan. Validasi terhadap peneliti sebagai instrumen meliputi validasi terhadap pemahaman metode penelitian kualitatif, penguasaan wawasan terhadap bidang yanag diteliti, kesiapan peneliti untuk memasuki obyek penelitian, baik secara akademik mauapun logistiknya. Dan yang melakukan validasi adalah peneliti itu sendiri, melalui evaluasi diri seberapa jauh pemahaman terhadap metode kualitatif, penguasaan teori dan wawasan terhadap bidang yang diteliti, serta kesiapan dan bekal. Untuk informan dalam penelitian ini yakni Accounting Staff dan Staff/Manager/geologi/supervisor yang berada di area kegiatan pertambangaan (yang bisa memberikan keterangan mengenai aktivitas pertambangan) di PT. Vale Indonesia.

\section{Metode Pengumpulan Data.}

Penelitian kualitatif merupakan suatu metode yang digunakan untuk meneliti pada kondisi objek yang alamiah, dimana peneliti adalah sebagai instrument kunci, teknik pengumpulan data dilakukan secara triangulasi. peneliti adalah instrument kunci. Oleh karena itu, peneliti harus memiliki bekal teori dan wawasan yang luas jadi bisa bertanya, menganalisis, dan mengonstruksi objek yang menjadi lebih jelas (Rustanto, 2015). Dalam penelitian kualitatif, pengumpulan data dilakukan pada natural setting (kondisi yang alamiah), sumber data primer, dan teknik pengumpulan data lebih banyak pada observasi berperan serta (participan observation), wawancara mendalam (in depth interview) dan dokumentasi (Sugiyono, 2012: 225).

\section{HASIL DAN PEMBAHASAN}

Temuan penelitian ini diperoleh dengan teknik ,observasi, dokumentasi, dan wawancara secara mendalam dengan informan sebagai bentuk pencarian data. Analisis ini yang menjadi objek 
dalam penelitian ini terfokus pada pihak bagian Accounting service yakni, Senior Manager Financial Reporting dan Senior Financial Analyst adapun pihak yang berada di lapangan yakni, manager sorowako outer area, engineering mining reklamasi, supervisor mining reklamasi dan foreman nursery.

Peneliti menggunakan metode kualitatif untuk melihat kondisi alami suatu fenomena yang terjadi. Peneliti kualitatif merupakan prosedur penelitian yang menghasilkan data-data deskriptif berupa kata-kata tertulis atau tulisan yang didasari oleh pihak atau pelaku yang diamati. Untuk tahap analisis, yang dilakukan oleh peneliti adalah membuat daftar pertanyaan untuk wawancara, kemudian mengumpulkan data, dan menganalisis data yang dilakukan oleh penelitian sendiri.

\section{Filosofi Eksplorasi}

Menurut Bapak Nasruddin N. Aslam (informan) tentang makna pengeluaran eksplorasi yang menyatakan yaitu:

"Eksplorasi itu kan. Kegiatan yang dilakukan oleh geologist untuk mencari cadangan di area kita”

Maksud dari pemahaman informan tentang eksplorasi yaitu, kegiatan yang dilakukan oleh geologist untuk mencari cadangan di area kita. pihak geologist yang dimaksud itu adalah pihak yang melakukan pencarian bahan galian yang ekonomis di daerah-daerah baru atau dalam artian daerah yang belum sama sekali dilakukan aktivitas penambangan, cadangan yang dimaksud adalah berupa mineral, emas, nikel ,sulfur , milerite, dan sebaganya.

Pihak geologist yang melakukan kegiatannya yakni mencari informasi atau data dimana keberadaan cadangan mineral tersebut. Tim eksplorasi tersebut terdiri dari pihak - pihak geologist, pihak survey geofisika, survey topografi, pihak drilling, pihak lab dan sebagainya. Pihak-pihak tersebut masing-masing memiliki tugasnya tersendiri.

Kegiatan eksplorasi merupakan kegiatan inti dari industry pertambangan maupun perminyakan, tanpa pencarian oleh tim eksplorasi kita tidak akan mengetahui dimana keberadaan sumber daya mineral. Kegiatan eksplorasi merupakan kegiatan inti sebelum masuk ke tahap operasi penambangan sampai produk tersebut di jual atau di kapalkan. Kegiatan yang dilakukan oleh tim eksplorasi tentu menelusuri daerah-daerah yang bahkan belum sama sekali di jelajahi.

\section{Klasifikasi Pengeluaran Eksplorasi}

Menurut Ibu Sultin Tingkaru (informan) tentang klasifikasi pengeluaran eksplorasi sebagai 
berikut:

"Begini di perusahaan ini untuk eksplorasi sendiri itu kita hanya mengenal adanya cost eksplorasi ada 2 eksplorasi yang di treat ke RND dan OPEX"

Maksud dari pemahaman informan tentang klasifikasi pengeluaran eksplorasi yaitu, untuk di PT Vale Indonesia pengeluaran eksplorasi ada 2 jenis yakni, ada cost eksplorasi untuk RND dan OPEX. RND (Research and Development) adalah biaya yang dikeluarkan sehubungan dengan pencarian cadangan mineral. Dan untuk OPEX (Operation Expenditure) adalah biaya yang dikeluarkan sehubungan dengan kegiatan operasi penambangan.

Pengeluaran eksplorasi di PT Vale adalah semua biaya yang dikeluarkan sehubungan dengan aktivitasnya seperti biaya perlengkapan, servis dan kontrak, biaya karyawan, biaya bahan bakar,dan biaya asuransi dan pajak. Semua biaya yang dikeluarkan nantinya akan di kategorikan yang mana akan masuk ke RND dan mana yang akan masuk ke OPEX sesuai dengan criteria masing-masing. Namun, biaya tersebut tetap menjadi cost eksplorasi yang nantinya akan di treat ke RND dan OPEX.

\section{Pengakuan Pengeluaran Eksplorasi}

Berdasarkan pernyataan dari informan (Pak Nasruddin N. Aslan) mengenai eksplorasi sebagai berikut.

"Cost eksplorasi, tetap kita akui cost eksplorasi dan tidak kita klasifikasikan bahwa cost eksplorasi itu untuk yang ini...."

Pengakuan untuk pengeluaran eksplorasi menurut informan di akui sebagai cost eksplorasi dan tidak di klasifikasikan berdasarkan jenisnya. Cost eksplorasi yang terdiri dari RND dan OPEX masing-masing memiliki cost elemen akan tetapi, tetap di akui bahwa pengeluaran eksplorasi tersebut sebagai cost eksplorasi.

Berikut pendapat informan (Pak Nasruddin N. Aslan) sebagai berikut.

"Nah, di eksplorasi itu kalau dia di RND dia itu pasti eee ... apa namanya, ja jarak dari titik bor dengan yang itu itu lumayan panjang, mereka itu punya dari jarak mulai dari 400 meter trus mereka nanti akan masuk ke 200 terus ke100. Kalau dia 100 dia ada nanti yang 50 . dan yang 50 ini nanti itu akan masuk ke OPEX karena jaraknya dia lebih pendek......Tujuannya kenapa dia itu pendek, yah dia itu lebih kepada confidence levelnya teman-teman geologist di eksplorasi untuk meyakinkan benar bahwa cadangan kita sebanyak ini yah mungkin lebih kepada itu sih. Dan yang saya pahami ini yah, di dalam 
tanah itu kan enggak ketahuan kan?"

Cost eksplorasi yang ada di PT. Vale ada 2 jenis cost didalamnya ada RND (Research and Development) dan OPEX (Operation Expenditure). Cost eksplorasi dari RND terdiri dari beberapa cost element, ketika aktivitas itu dilakukan mulai dari tahap pencarian sampai melakukan pengeboran itu akan di akui sebagai RND. RND ini merupakan biaya dikeluarkan dalam rangka pencarian, penelitian, dan pengembangan untuk mengetahui keberadaan sumberdaya mineral yang ekonomis bagi perusahaan. Sedangkan untuk Opex adalah biaya yang dikeluakan sehubungan dengan aktivitas operasi dalam tahap penambangaan.

Perlakuan untuk pengeluaran eksplorasi merupakan suatu praktik bagaimana perusahaan mengaplikasikan biaya atas pengeluaran dari kegiatan yang dilakukan. Pengeluaran eksplorasi di perusahaan pertambangan maupun perminyakan merupakan pengeluaran dalam rangka mencari cadangan sumber daya alam yang belum diketahui, aktivitas eksplorasi tentu tidak mengeluarkan biaya yang sedikit karena adanya pengeluaran yang dilakukan untuk kegiatan tersebut dan melibatkan banyak pihak-pihak dalam tim eksplorasi yang memasuki area-area yang bahkan sama sekali belum pernah di lalui.

Perlakuan akuntansi untuk pengeluaran eksplorasi telah di atur dalam IFRS 6 (International Financial Reporting Standars) Exploration for and Evaluation of Mineral Resources yang kemudian telah di adopsi Indonesia yaitu PSAK No.64 Eksplorasi dan Evaluasi sumber Daya Mineral yang secara khusus memberikan acuan atau pedoman dalam menerapkan perlakuan pengeluaran eksplorasi. Tingginya pengeluaran eksplorasi untuk mencari cadangan mineral, maka dibutuhkan suatu kebijakan akuntansi yang tepat harus digunakan untuk memperhitungkan biaya-biaya tersebut.

Berikut pernyataan yang diberikan informan terkait perlakuan untuk pengeluaran eksplorasi apakah di akui sebagai aset di PT Vale Indonesia oleh Ibu Sultin Thengkaro.

"kalau tentang aset eksplorasi kita nggak ada yah, nggak tau kalau perusahaan lain karena disini kita hanya memperlakukan cost itu se simple mungkin. ...."

Berdasarkan pernyataan informan mengenai pengeluaran eksplorasi apakah di akui sebagai aset eksplorasi dan evaluasi sesuai dengan adanya standar akuntansi yaitu PSAK No. 64 yaitu, bahwa perlakuan untuk pengeluaran eksplorasi tidak di akui sebagai aset di PT Vale dan menurut informan merasa tidak mengetahui apakah perusahaan lain juga menerapkan hal yang sama atau sebaliknya 
Vol. 05 No. 02 Juni

ISSN 2339-1502

\section{Kepatuhan Terhadap Standar Akuntansi}

Standar akuntansi terkait aktivitas pertambangan yang cukup unik dalam industry pertambangan yaitu adanya aktivitas eksplorasi. Banyaknya pengeluaran yang dikeluarkan dalam aktivitas ini maka, dibutuhkan suatu kebijakan akuntansi yang tepat agar memudahkan dalam pengambilan keputusan dan membuat laporan keuangan menjadi akurat dan relevan.

Namun, dalam pernyataan PSAK No. 64 dalam pragraf 12 berbunyi:

"Entitas dapat mengubah kebijakan akuntansinya atas pengeluaran eksplorasi dan evaluasi jika perubahan kebijakan tersebut dapat memberi laporan keuagan menjadi lebih relevan bagi kebutuhan pengguna dalam pengambilan keputusan dan andal, atau lebih andal dan relevan bagi pengambil keputusan. Entitas mempertimbangkan unsure relevan dan keandalan dengan menggunakan criteria dalam PSAK25 (revisi 2009): Kebijakan akuntansi, perubahan Estimasi Akuntansi dan kesalaha”.

Dari pernyataan tersebut menunujukkan bahwa entitas diperbolehkan untuk tidak menerapakan kebijakan akuntansi atas pengeluaran eksplorasi sebagai Aset Eksplorasi dan Evaluasi (Aset $E \& E)$ jika terbukti bahwa penerapan kebijakan akuntansi yang diterapkan dapat membuat laporan keuangan menjadi lebih relevan, andal atau lebih andal lagi bagi para pengguna atau stakeholder.

Berikut pernyataan dari informan Ibu Sultin Thengkaro mengenai adanya Standar akuntansi yang mengatur aktivitas eksplorasi yaitu, PSAK No.64 sebagai berikut.

"Bukan berarti kita nggak menerapkan, lagi pula yang mengaudit laporan ini kan pak Budi

Susanto (auditor dari KPMG) dan dia juga salah satu pembuat dan tim penyusun SAK juga dan lagi pula dia juga nggak ada menyinggung mengenai kepatuhan”

Dari pernyataan informan tersebut bahwa perusahaan tersebut tidak bermaksud untuk tidak menerapkan adanya suatu standar yang telah di atur dalam PSAK No. 64, sesuai dengan pernyataan dalam paragraph 12 dalam PSAK No.64 bahwa entitas diperbolehkan untuk mengubah kebijakan akuntansinya jika perubahan dari kebijakan akuntansi yang diterapkan tersebut dapat membuat laporan keuangan lebih relevan dan andal.

\section{PENUTUP}

\section{Simpulan}

Praktik akuntansi untuk pengeluaran eksplorasi pada perusahaan pertambangan sangat penting untuk mengetahui bagaimana kebijakan akuntansi yang diterapkan pada perusahaan tersebut. tingginya pengeluaran pada aktivitas eksplorasi karena kegiatan tersebut bersifat gambling atau 
untung-untungan. Adanya suatu Standar akuntansi yaitu, PSAK No.

64 bahwa seluruh kegiatan eksplorasi selain pengembangan di akui sebagai suatu Aset eksplorasi dan evaluasi dan di uji penurunan nilainya sesuai PSAK yang bersangkutan. Namun, dalam paragraph 12 PSAK No. 64 berisi penegasan bahwa entitas dapat mengubah kebijakan akuntansinya jika memungkinkan kebijakan akuntansi lainnya dapat membuat lebih relevan dan lebih andal.

Untuk pengeluaran eksplorasi di PT Vale Indoensia mengakuinya sebagai suatu Cost yaitu, cost eksplorasi dan nantinya akan dibebankan sesuai jenis eksplorasi apakah RND (research and development) atau OPEX (operation expenditure). Adanya standar akuntansi hasil dari adopsi dari IFRS yang telihat bahwa dalam PSAK No. 64 ada pengecualian untuk penerapan kebijakan akuntansi, bahwa jika entitas memiliki kebijakan akuntansi yang lebih relevan, maka entitas boleh menerapkan kebijakan akuntansi yang lain. Hal tersebut menandakan bahwa terjadi ketidakseragaman dalam pelaporan keuangan, seperti yang kita pahami bahwa adanya suatu standar akuntansi yakni, selain relevan, andal, akuntabel, transparansi dan juga agar terjadi keseragaman dalam pelaporan keuangan.

\section{Saran}

Penelitian ini merupakan Studi fenomenologi yang memiliki banyak keterbatasan. Pengumpulan data yang dilakukan dalam penelitian ini adalah dengan teknik wawancara, namun banyak hambatan yang terjadi saat proses wawancara berlangsung. Maka dari itu, peneliti memandang perlu diadakan penelitian lanjutan dengan penambahan informan yang berkaitan langsung seperti Auditor dan pihak yang paham mengenai Standar Akuntansi

\section{DAFTAR PUSTAKA}

Abdo, Hafez. 2018. Accounting for Extractive Industries : Controversion and a Need For Harmonisation. Energy Resource Journal. Vol 1. No.9. https://www.researchgate.net (Diaksse 18 Juli 2019).

Basrowi dan Sudikin. 2002. Metode Penelitian Kualitatif Perspektif Mikro. Surabaya: Insan Cendekia.

Bilitania, Rizka. 2015. Accounting For Mineral Resources : Literture Review Full cost Accounting versus Succes Effort. Thesis. Rotterdam. International Bachelor of Economics and Business Economics Erasmus Universiteit Rotterdam.

Burhany, Dian Imania. 2014. Pengaruh Implementasi Akuntansi Lingkungan Terhadap Kinerja Lingkungan Dan Pengungkapan Informasi Lingkungan (Studi Pada Perusahaan Pertambangan Umum Yang Mengikuti Proper Periode 2008-2009). Proceedings SNEB. 
Vol. 05 No. 02 Juni

ISSN 2339-1502

Makassar.

Cahyonowati, Nur \& Ratmomo, Dwi. 2012. Adopsi IFRS dan Relevansi Nilai Informasi Akuntansi. Jurnal Akuntansi dan Keuangan. Vol.14 No.2. https://doi.org/10.9744/jak.14.2.105-115 (Diakses pada 19 Juli 2019).

Cortese, C. L., Irvin, H. J., \& Kaidonis, M. A. (2010). Powerful players: how constituents captured the setting of IFRS 6, an accounting standard for the extractive industries. Accounting Forum 34, 76-88.

Daulay, Maraimbang. 2010. Filsafat Fenomenologi. Medan: Pandjiaswaja Press. Dina, Farah. 2016. Pengaruh Aktivitas Pengelolaan Lingkungan Hidup Terhadap Kinerja Keuangan Perusahaan Pertambangan Yang Terdaftar di Bursa Efek Indonesia. Skripsi. Bandar Lampung: Fakultas Ekonomi dan Bisnis Universitas Lampung.

Dwipuspasari, Evi. 2011. Analisis Peneraapan Psak 33 (Revisi 2011) Akuntansi Pertambangan Umum Pada PT. Bukit Asam ( Persero ) Tbk. Skripsi. Depok: Fakultas Ekonomi Universitas Indonesia.

Fardani, Andi. 2012. Dampak Sosial Keberadaan PT Vale Indonesia Tbk Terhadap Kehidupan Masyarakat (Studi Kasus Sorowako Kecamatan Nuha Kabupaten Luwu Timur ). Skripsi. Makassar: Fakultas Sosial dan Ilmu Politik Universitas Hasanuddin Makassar.

Fitrah, Muhammad dan Luthfiyah. 2017. Metodologi Penelitian; Penelitian Kualitatif, Tindakan Kelas \& Studi Kasus. Sukabumi: Cv Jejak.

Ghozali, Imam dan Chairi, Anis. 2007. Teori Akuntansi, Edisi Ketiga. Semarang: Badan Penerbit Universitas Dipenegoro.

Ikatan Akuntan Indonesia. 2012. Standar Akuntansi Keuangan. Jakarta: Ikatan Akuntan Indonesia.

Kamayanti Ari. 2016. Metodologi Penelitian Kualitatif Akuntansi: Pengantar Religiositas Keilmuan. Yayasan Rumah Peneleh Jakarta Selatan.

Khaled Samaha and Hichem Khlif. 2016. Adoption of and compliance with IFRS in developing countries. Journal of Accounting in Emerging Economies, Vol. 6 no. 1. (Diakses Tanggal 01 Desember 2018).

Kieso, Donald E., Weygandt, Jerry J.,dan Warfield Terry D. 2008. Akuntansi Intermediate. Edisi 12. Jakarta: Erlangga.

Krishantoro, Gregorius Adhytama. 2017. Analisis Pengungkapan Biaya Aktivitas Kontruksi, Produksi, Serta Pengelolaan Lingkungan Hidup) Terhadap Return On Investment Pada Perusahaan Pertambangan Yang Terdaftar di Bursa Fek Indonesia. Skripsi. Yogyakarta: Program Studi Akuntansi Jurusan Akuntansi Fakultas Ekonomi Universitas Sanata Dharma.

Kulikova L.I.,Gubaidurlina., Arzhantseva N.L. 2014. The Need of Profesional Judgment of The Accountant in Accountng Assets of Exploration and Evaluation of Mineral Resources. Mediterranean Journal of Social Science. Vol 5 No.24. (Diakses Tanggal 18 Juli 2019).

Kurniawan, Rizkie Arie. 2017. Dampak Kebijakan Perizinan Pertambangan Terhadap Kerusakan Lingkungan Bukit Camang Bandar Lampung. Skripsi. Bandar Lampung: Fakultas Ilmu Sosial Dan Politik Universitas Lampung. 
Vol. 05 No. 02 Juni

ISSN 2339-1502

Martani, Dwi et al., 2014. Akuntansi Keuangan Menengah Berbasis PSAK. Jakarta: Salemba Empat.

Nathania, Stephanie. 2013. Analisis Penerapan Psak No. 33 ( Revisi 2011) dan PSAK No. 64 /IFRS 6 Antara Perusahaan Pertambangan Yang Terdaftar Di Bursa Efek Indonesia Dan Bursa Efek Australia. Thesis. Jakarta: Universitas Bina Nusantara.

Nurdin., Sudirman et al., 2018. Pengantar Akuntansi Untuk Korporasi. Malang: Empatdua.

Pamungkas, Noto dan Rusherlistyani. 2015. Penerapan IFRS 6 dalam Psak 64. Journal Of Economic \& Social Vol: 1 No. 1 Hal: 67-77. (Diakses Tanggal 01 Desember 2018).

Pernyataan Standar Akuntansi Keuangan (PSAK) No. 33 Tahun 2011 tentang Aktivitas Pengupasan Lapisan Tanah dan Pengelolaan Lingkungan Hidup Pada Pertambangan Umum.

Pernyataan Standar Akuntansi Keuangan (PSAK) No. 64 Tahun 2011 tentang Eksplorasi dan Evaluasi Sumber Daya Mineral.

Prasetyo, Priyono P. 2015. Evaluasi Terhadap PSAK No. 29 Akuntansi Minyak \& Gas Bumi. Journal Akuntansi \& Investasi Vol : 1 No. 1.

Interpretasi Standar Akuntansi Keuangan (ISAK) No. 29 Tahun 2014 tentang Biaya Pengupasan lapisan Tanah dalam Tahap Produksi Pada Tambang Terbuka.

Qanun Aceh No. 15 Tahun 2013 tentang Pengelolaan Pertambangan Mineral Dan Batubara. 2013. Nanggroe Aceh Darussalam.

Riveta, Oksidea. 2012. Implementasi Psak No. 64 Tentang Perlakuan Akuntansi Biaya Eksplorasi dan Evaluasi (Studi Kasus pada PT. Medco Energi International Tbk). Jurnal Ilmiah Mahasiswa Fakultas Ekonomi dan Bisnis. Vol: 1 No. 2. (Diakses Tanggal 13 Desember 2018).

Rustanto, Bambang. 2015. Penelitian Kualitatif Pekerjaan Sosial. Bandung: PT Remaja Rosdakarya.

Usman, Arif Fuddin. 27 oktober 2018. Jernihnya Air Danau Matano, Ada Kontribusi PT. Vale Menjaganya Dari Cemaran Bahan Kimia. makassar.tribunnews.com. (Akses 01 Februari 2019).

Santana, Septiawan. 2010. Menulis Ilmiah Metodologi Penelitian Kualitatif. Edisi Kedua. Jakarta: Yayasan Pustaka Obor Indonesia.

Sapar. 2017. Pengantar Metode Penelitian. Bogor: Makaira Printing Plus.

Sekaran, Uma. 2009. Research Methods For Business. Jakarta: Salemba Empat.

Setiadi et al., 2018. Pengantar Akuntansi. (A. Feryanto, Ed.). Jakarta: Penerbit Cempaka Putih.

Sitorus, Novanti, J,. \& Ardiati, A.Y. 2017. Pengaruh Standar Akuntansi Keuangan Indonesia Baru, Ukuran Kantor Akuntan Publik, Ukuran Perusahaan Dan Umur Perusahaan Terhadap Audit Report Lag. MODUS-Jurnal Ekonomi dan Bisnis. Vol.29 No.2.

Sudrajat, Nandang. 2013. Teori Dan Praktik Pertambangan Indonesia. Yogyakarta: Medpress Digital.

Sugiyono. (2009). Metode Penelitian Kuantitatif, Kualitatif Dan R\&D. Bandung: Alfabeta. 

. 2012. Metode Penelitian Kuantitatif, Kualitataif, Dan R\&D. Bandung. Alfabeta.

Undang Undang Republik Indonesia No. 4 Tahun 2009 Tentang Pertambangan Mineral Dan Batu Bara.

Widagdya, Fiqhan. Pranata. 2014. Peranan PSAK No. 33 Pada Perusahaan Pertambangan Di Indonesia. Journal Akuntansi, Vol: 2 No. 3. (Diakses tanggal 20 Oktober 2018).

Yusuf, A. M. (2017). Metode Penelitian. Jakarta: Penerbit Fajar Interpratama Mandiri.

Zamzani, F., \& Nusa, N. D. (2016). Pengantar Akuntansi I. Yogyakarta: Gadjah Mada University Press. 